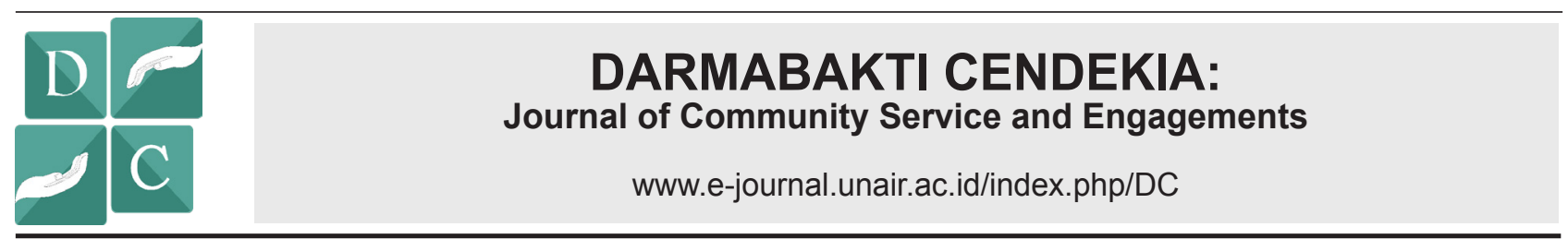

\section{TRAINING AND ASSISTANCE AN NISAA' QURAN RECITATION GROUP RUNGKUT IN UTILIZING TANAMAN OBAT KELUARGA (TOGA) INTO HERBAL PRODUCTS}

\author{
PELATIHAN DAN PENDAMPINGAN KELOMPOK PENGAJIAN \\ AN NISAA' RUNGKUT DALAM PEMANFAATAN TANAMAN OBAT \\ KELUARGA MENJADI PRODUK HERBAL
}

Scope:

Health

\author{
Rini Hamsidi ${ }^{*}$, Dwi Setiani Sumardiko ${ }^{1}$, Ilkafah Ilkafah ${ }^{2}$, Edith Frederika Puruhito ${ }^{1}$, Ratna \\ Wahyuni $^{1}$, Maya Septriana ${ }^{1}$, Myrna Adianti ${ }^{1}$, Ario Imandiri ${ }^{1}$, Taufiqurahman Sidqi ${ }^{3}$ \\ ${ }^{1}$ Study Program of Traditional Medicine, Faculty of Vocational Studies, Universitas Airlangga, Surabaya-Indonesia \\ ${ }^{2}$ Study Program of Nursing, Faculty of Vocational Studies, Universitas Airlangga, Surabaya-Indonesia \\ ${ }^{3}$ Study Program of Medical Laboratory Technology, Faculty of Vocational Studies, Universitas Airlangga, Surabaya-Indonesia
}

\section{A B S T R A C T}

Background: The corona virus pandemic (COVID-19) is spreading rapidly in a number of countries, including Indonesia. In order to deal with the increasingly widespread COVID-19, the government has established health and safety protocols by staying at home and maintaining distance, washing hands frequently with soap with running water or using hand sanitizers and increasing the body's immune system. One way to increase the immune system is through the use of Family Medicinal Plants (TOGA). Purpose: Transfer of knowledge and technology to An Nisaa 'study group partners through counseling on the use of TOGA by using appropriate technology to produce natural Hand Sanitizer products and instant herbal empon-empon in powder form which makes it easier to use daily. Methods: Methods of extension (lectures and discussions), training and mentoring using the Good Traditional Medicine Manufacturing Method (CPOTB) in producing natural Hand Sanitizer products and instant herbal medicine. Results: The expected result of this program is the use of TOGA by the community, especially partners to produce immune system-enhancing herbal products that are safe and can be stored for a long time to maintain health, especially families during the COVID 19 pandemic. Conclusion: This program increased knowledge and the skills of the An Nisaa 'Rungkut recitation group seen from the enthusiasm and ability of the participants in following and practicing the making of herbal medicine and hand sanitizers.

\section{A B S T R A K}

Latar belakang: Pandemi virus corona (COVID-19) menyebar cepat di sejumlah negara, termasuk di Indonesia. Guna mengatasi COVID-19 makin meluas, pemerintah menetapkan protokol kesehatan dan keselamatan dengan tetap di rumah dan menjaga jarak, sering mencuci tangan pakai sabun dengan air mengalir atau gunakan hand sanitizer serta meningkatkan sistem imun tubuh. Salah satu cara untuk meningkatkan sistem imun melalui pemanfaatan Tanaman Obat Keluarga (TOGA). Tujuan: Transfer ilmu pengetahuan dan teknologi kepada mitra kelompok Pengajian An Nisaa' melalui penyuluhan tentang pemanfaatan TOGA dengan menggunakan teknologi tepat guna untuk menghasilkan produk Hand Sanitizer alami dan jamu empon-empon instan dalam bentuk serbuk yang lebih memudahkan dalam penggunaannya sehari-hari. Metode: Metode penyuluhan (ceramah dan diskusi), pelatihan dan pendampingan menggunakan metode Cara Pembuatan Obat Tradisional yang Baik (CPOTB) dalam menghasilkan produk Hand Sanitizer alami dan jamu instan. Hasil: Hasil yang diharapkan dari program ini adalah pemanfaatan TOGA oleh masyarakat khususnya mitra untuk menghasilkan produk jamu peningkat sistem imun yang aman dan dapat disimpan dalam jangka waktu lama untuk menjaga kesehatan khususnya keluarga selama masa pandemi COVID 19. Kesimpulan: Program pengabdian ini menambah ilmu pengetahuan dan keterampilan kelompok pengajian An Nisaa' Rungkut dilihat dari antusias dan kemampuan peserta dalam mengikuti dan mempraktekkan pembuatan jamu dan hand sanitizer.

\author{
ART I CLE INFO \\ Recieved 20 September 2020 \\ Accepted 14 November 2020 \\ Online 6 Desember 2020 \\ *Correspondence (Korespondensi): \\ Rini Hamsidi \\ E-mail: \\ rini.hamsidi@vokasi.unair.ac.id
}

\section{Keywords:}

Jamu; Antiseptic; TOGA; Immune system

Kata kunci:

Jamu; Antiseptik; TOGA;

Sistem imun 


\section{PENDAHULUAN}

Tanaman Obat Keluarga (TOGA) adalah tanaman hasil budidaya rumahan yang berkhasiat sebagai obat, dimanfaatkan dalam upaya peningkatan kesehatan baik preventif, promotif maupun kuratif. Umumnya TOGA dimanfaatkan sebagai minuman kebugaran, ramuan untuk gangguan kesehatan ringan berdasarkan gejala, ramuan khusus untuk lansia dan memelihara kesehatan ibu serta meningkatkan gizi anak (Kemenkes, 2011).

Awal tahun 2020, COVID-19 menjadi masalah kesehatan dunia. Pandemi virus corona (Covid-19) menyebar cepat di sejumlah negara, termasuk di Indonesia. Coronavirus Disease (COVID-19) adalah virus jenis baru yang belum pernah diidentifikasi sebelumnya pada manusia. Gejala klinis biasanya muncul dalam 2 hari hingga 14 hari setelah paparan. Tanda dan gejala umum infeksi coronavirus antara lain gangguan pernafasan akut seperti demam, batuk, pilek, letih, lesu, sakit tenggorokan dan sesak napas. Pada kasus yang berat dapat menyebabkan pneumonia, sindrom pernafasan akut, gagal ginjal dan bahkan kematian (Kemenkes, 2020).

Guna mengatasi Covid-19 makin meluas, pemerintah menetapkan protokol kesehatan dan keselamatan dengan tetap di rumah dan menjaga jarak, tidak merokok, aktivitas fisik/senam, membersihkan benda yang sering disentuh dengan desinfektan, istirahat yang cukup, konsumsi gizi seimbang dan lebih sering mencuci tangan pakai sabun dengan air mengalir atau gunakan hand sanitizer serta meningkatkan sistem imun tubuh.

Salah satu cara untuk meningkatkan sistem imun melalui pemanfaatan tanaman obat keluarga (TOGA) yang dikenal dengan empon-empon sebagai jamu atau minuman herbal. Temulawak (Curcuma xanthoriza), Jahe merah (Zingiber officinale), Kunyit (Curcuma domestica) termasuk dalam tanaman obat unggulan. Tanaman rempah (empon-empon) yang mengandung kurkumin dan gingerol aman untuk digunakan sebagai minuman herbal atau diolah dalam bentuk sediaan serbuk instan. Herbal khususnya kunyit dan temulawak mengandung kurkumin, sedangkan jahe mengandung gingerol yang dapat meningkatkan daya tahan tubuh bila diminum secara rutin.

Langkanya hand sanitizer di pasaran sehingga kita dapat memanfaatkan tanaman TOGA yang digunakan sebagai antiseptik alami yaitu daun sirih dalam penanggulangan penyebaran Covid-19. Daun sirih mengandung senyawa karvakol yang memiliki manfaat sebagai desinfektan dan antijamur, serta tannin sebagai antiseptik.

Berdasarkan uraian di atas, maka perlu adanya penyuluhan, pembinaan dan pendampingan kepada masyarakat terutama kelompok pengajian, PKK atau ibu rumah tangga dalam memanfaatkan tanaman obat keluarga sebagai bahan baku produk jamu instan dan hand sanitizer alami untuk meningkatkan sistem imun keluarga maupun lingkungan di sekitarnya.

\section{METODE}

\section{Tempat}

Program Pengabdian ini dilaksanakan di Kecamatan Rungkut, Surabaya pada tanggal 26 September 2020. Kegiatan ini dihadiri 31 orang peserta yang merupakan ibu-ibu dari kelompok Pengajian An-Nisaa' Rungkut.

\section{Pelaksanaan}

Metode ceramah, pelatihan dan pendampingan yang digunakan pada kegiatan Pengabdian ini bertujuan untuk membina dan meningkatkan pengetahuan kelompok ibu-ibu pengajian mengenai Tanaman Obat Keluarga serta manfaat yang dapat diperoleh melalui pembuatan produk hand sanitizer alami dan jamu emponempon instan. Adapun kegiatan yang dilaksanakan dalam beberapa tahapan yaitu: 1). Penyuluhan dengan menggunakan metode ceramah untuk menjelaskan manfaat penggunaan tanaman obat sebagai bahan baku jamu yang dapat digunakan dalam kehidupan sehari-hari dan menjadi produk yang memiliki nilai lebih dalam hal bentuk dan khasiatnya. Materi lainnya yang diberikan selama penyuluhan tentang tanaman obat keluarga yang memiliki khasiat dalam meningkatkan sistem imun dan jenis tanaman obat keluarga yang telah melalui uji klinis. Namun sebelum dilaksanakan penyuluhan, setiap peserta mengikuti pretest untuk mengetahui tingkat pemahaman peserta tentang Tanaman Obat Keluarga dan pemanfaatannya dalam meningkatkan kesehatan. 2). Pelatihan cara pembuatan hand sanitizer alami dari bahan baku daun sirih dan serbuk jamu instan dari empon-empon yang sesuai dengan CPOTB. 3) Pendampingan produksi serbuk instan dan hand sanitizer alami.

\section{Evaluasi}

Evaluasi dirancang untuk meningkatkan pengetahuan dan keterampilan pihak mitra terhadap teori dan praktek yang telah diberikan. Evaluasi dirancang dengan pengerjaan soal pre test dan post test yang berkaitan dengan teori dan praktek yang telah diberikan. Selain itu, evaluasi juga dilakukan untuk pembuatan hand sanitizer dan jamu empon-empon instan. Evaluasi produkproduk tersebut meliputi evaluasi kuantitatif dan kualitatif. Evaluasi kuantitatif dinilai dari 
jumlah produk yang dihasilkan sedangkan evaluasi kualitatif yang meliputi warna, bau, rasa, keseragaman bobot, keseragaman ukuran dan derajat kehalusan serbuk, serta kestabilan produk dalam penyimpanan.

\section{HASIL DAN PEMBAHASAN}

Kegiatan penyuluhan, pelatihan dan pendampingan pada kelompok pengajian AnNisaa' Rungkut Kidul merupakan Program Kemitraan Masyarakat "Pemanfaatan Tanaman Obat Keluarga (TOGA) Menjadi Produk Hand Sanitizer Alami dan Jamu Peningkat Sistem Imun di Kelurahan Rungkut Kidul Kecamatan Rungkut Surabaya" pada ibu-ibu kelompok pengajian An'Nissa dan PKK Kelurahan Rungkut Kidul telah dilaksanakan dengan lancar di hotel sesuai dengan protokol kesehatan dalam era new normal dengan selalu memperhatikan $3 \mathrm{M}$ karena masih tingginya angka positif Covid-19 di Surabaya. Penyuluhan yang dilaksanakan secara online berjalan dengan baik karena adanya antusias mitra dalam mengikuti program ini. Daftar peserta yang mengikuti kegiatan berjumlah 31 orang (Tabel 1). Adapun penyuluhan kedua yaitu seminar online dengan mengikutsertakan mitra, mahasiswa, akademisi, praktisi dan masyarakat agar pemahaman tentang pemanfaatan obat tradisional lebih diterima oleh masyarakat luas (Gambar 1). Pada penyuluhan kedua materi yang diberikan meliputi Covid-19 dan penanganannya, pemanfaatan tanaman obat keluarga dan sehat dengan jamu.

Tabel 1. Daftar Nama Anggota Kelompok Pengajian AnNissa' Rungkut Asri Barat

\begin{tabular}{cccc}
\hline No & Nama & No & Nama \\
\hline 1 & Aisyah Fakhri & 17 & Susyanto \\
2 & Didik Rosyadi & 18 & Suherman Noor \\
3 & Mahmud Said & 19 & Bambang SS \\
4 & Asti Yustianto & 20 & Unggul Yudianto \\
5 & Henny Natsir & 21 & Nasim \\
6 & Supi'is & 22 & Siti Hafsah \\
7 & Darmawan & 23 & Wulan BB \\
8 & Titi Agus S & 24 & Sulistyo \\
9 & Surachman & 25 & Tarwijan \\
10 & Indah Agus Santoso & 26 & Umi Kulsum \\
11 & Mas'udah Riyanto & 27 & Farida \\
12 & A.Irfan & 28 & Gris \\
13 & Asti Hartadi & 29 & Inoni \\
14 & Alie Maskun & 30 & Sari Susanto \\
15 & J.R Pantaw & 31 & Djoko Susilo \\
16 & Sanusi Husen & & \\
\hline
\end{tabular}

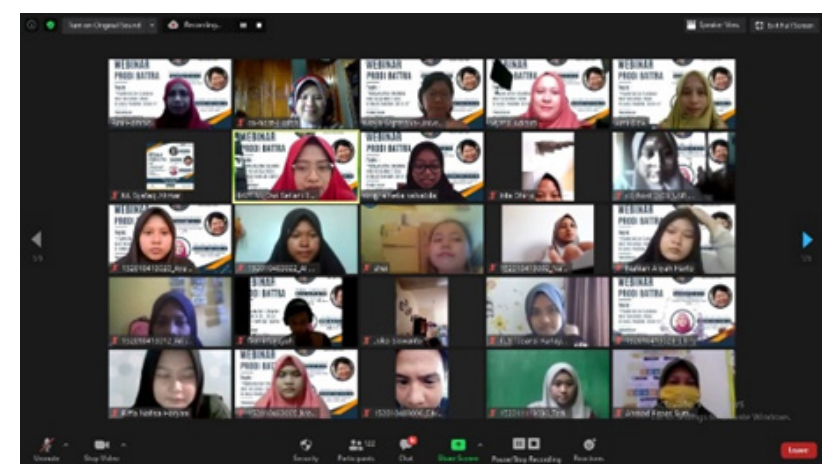

Gambar 1. Foto Kegiatan Seminar Online

Pelatihan dan pendampingan yang dilaksanakan berjalan dengan baik atas kerjasama dengan mitra yang sangat antusias mengikuti serangkaian acara dalam program ini. Dalam pelatihan dan pendampingan kepada mitra tidak mengalami kendala karena teknologi yang digunakan sangat sederhana dalam pembuatan sediaan jamu instan dan hand sanitizer alami. Demo pembuatan sediaan jamu dilakukan oleh tim pelaksana pengabdian masyarakat dengan video zoom sehingga bisa disaksikan oleh peserta secara online (Gambar 2). Peserta dibekali dengan booklet cara pembuatan jamu yang dapat langsung dicobakan dengan mudah dan cepat di rumah. Booklet tiap peserta berisi ramuan jamu beras kencur, kunir asam, wedang jahe madu, wedang pokak, dan wedang uwuh. Bahan-bahan yang digunakan pada saat pelatihan yaitu, jahe, kencur, pala, cengkeh, kayu manis, temulawak, kapulaga, secang, dan daun pandan.

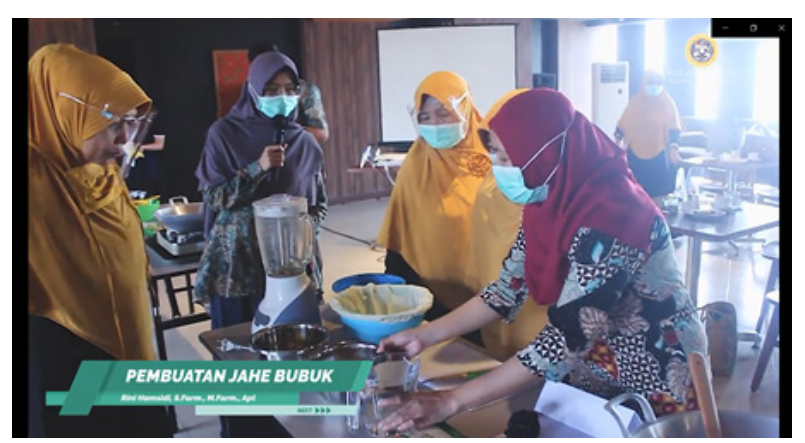

Gambar 2. Cara pembuatan jamu instan jahe

Untuk pembuatan hand sanitizer alami juga sangat mudah yaitu cukup memasak dengan proses double boiler (tim). Panci diisi dengan air, direbus sampai mendidih. Kemudian diatasnya dimasukkan baskom stainless steel berisi air satu gelas belimbing dan 10 lembar daun sirih yang dicacah. Setelah itu, air disaring dan siap digunakan untuk hand sanitizer maupun bahan baku disinfektan. Produk hand sanitizer dikemas dalam botol semprot kecil yang mudah dibawa kemanapun (Gambar 3). Lama masa simpan 
ekstrak daun sirih jika disimpan rapat di kulkas bisa bertahan satu bulan. Kalau langsung digunakan dan terpapar udara, hanya bertahan tiga hari.

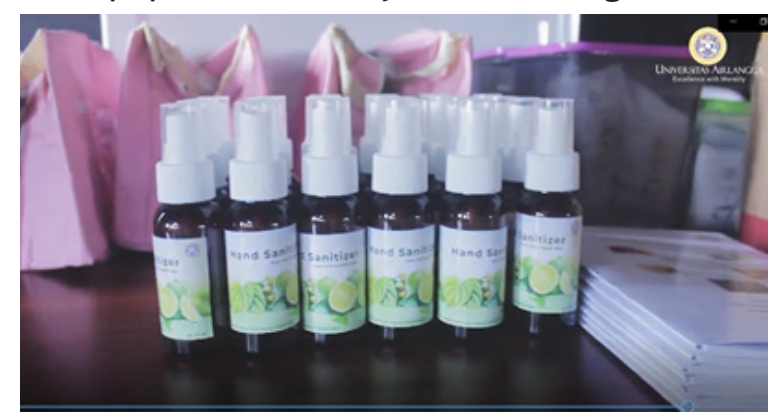

Gambar 3. Produk hand sanitizer

\section{KESIMPULAN DAN SARAN}

Program kemitraan masyarakat pemanfaatan tanaman obat keluarga (TOGA) menjadi produk hand sanitizer alami dan jamu peningkat sistem imun meningkatkan pemahaman, pengetahuan dan keterampilan ibu-ibu kelompok pengajian An-Nisaa' Rungkut Kidul Kecamatan Rungkut Surabaya.

\section{UCAPAN TERIMA KASIH}

Terima kasih yang sebesar-besarnya kami ucapkan kepada kelompok pengajian An Nisaa' Rungkut yang telah bersedia menjadi mitra pada program pengabdian masyarakat ini. Terima kasih juga penulis sampaikan kepada LPPM dan Fakultas Vokasi Universitas Airlangga yang telah mendanai program ini berdasarkan kontrak no 532/UN3/2020. Penulis menyatakan tidak ada konflik kepentingan dengan pihak-pihak yang terkait dalam kegiatan pengabdian kepada masyarakat ini.

\section{DAFTAR PUSTAKA}

Kementerian Kesehatan RI. 2011. 100 Top Tanaman Obat Indonesia. Jakarta: Badan Penelitian dan Pengembangan Kesehatan Balai Besar Penelitian dan Pengembangan Tanaman Obat dan Obat Tradisional. Diakses tanggal 30 Maret 2020.

Kementerian Kesehatan Republik Indonesia, 2020. Pedoman Kesiapsiagaan menghadapi Coronavirus Disease (Covid-19). Direktorat Jenderal Pencegahan dan Pengendalian Penyakit. Diakses tanggal 30 Maret 2020. 